ISSN : $2302-1590$

E-ISSN: $2460-190 \mathrm{X}$

ECONOMICA

Journal of Economic and Economic Education Vol.4 No.1 (124-135)

\title{
KUALITAS HIDUP KOMUNITAS PEMULUNG DI TEMPAT PEMBUANGAN AKHIR (TPA) AIR DINGIN KOTA PADANG DI TINJAU DARI SEGI PENDIDIKAN
}

\author{
Wati \\ Dosen Program Studi Pendidikan Ekonomi STKIP- PGRI Sumbar \\ Jl. Gunung Pangilun No.1, Padang Sumatera Barat \\ Email : tegowati73@gmail.com
}
Submitted: 2016.06.19 Reviewed: 2016.06.22 Accepted: 2016.06.24
http://dx.doi.org/10.22202/economica.2015.v4.i1.626

\begin{abstract}
This paper analyzes about life quality of scavenger community in the final disposal (TPA) Air Dingin Balai Gadang District Koto Tangah Village Padang. Scavengers are people who work collecting scrap things that are not longer useful by households, markets, offices, which have economic value. The research aims to reveal about the life quality of scavenger community in the final disposal Air Dingin seen from the aspect of education. Research methodology used is a qualitative approach. The data collection methods used are observation, interviews, documentation. The Informant sellected by using purposive sampling technique. The informants in this study are a scavenger community in TPA Air Dingin. The technique ensures of the data validation are refered to the use of Lincoln and Guba standard, namely credibility, transferability, dependability, conformability. Data analysis techniques are used data reduction step, data presentation, and conclusion. The results of this research revealed that scavengers have a high motivation to be able to change the fate out of poverty that has been felt, whatever they will done to educate their children and raise a family. They have high spirit, not affected by the weather, they still go to the trash in the morning in order to get more results, which means getting more money. It has been apparent the change of scavengers lives in the landfill of Air Dingin towards a better life, even it takes long time.
\end{abstract}

\begin{abstract}
Abstrak
Makalah ini menganalisis tentang kualitas kehidupan masyarakat pemulung di Tempat Pembuangan Akhir (TPA) Air Dingin Balai Gadang Kecamatan Koto Tangah Padang. Pemulung adalah orang-orang yang bekerja mengumpulkan barang bekas yang tidak lagi berguna atau dipakai oleh rumah tangga, pasar, kantor, yang memiliki nilai ekonomis. Penelitian ini bertujuan untuk mengungkapkan tentang kualitas kehidupan masyarakat pemulung di TPA Air Dingin dilihat dari segi pendidikan. Metodologi penelitian dengan pendekatan kualitatif. Metode pengumpulan data menggunakan tehnik observasi, wawancara, dokumentasi. Teknik pemilihan informan menggunakan purposive sampling. Informan dalam penelitian ini adalah komunitas pemulung di TPA Air Dingin. Teknik menjamin keabsahan data mengacu kepada penggunaan standard dari Lincoln dan Guba yaitu credibility, transferability, dependability, confirmability. Analisis data menggunakan langkah reduksi data, penyajian data, dan penarikan kesimpulan. Hasil penelitian ini mengungkapkan bahwa pemulung memiliki semangat yang tinggi untuk bisa merubah nasib keluar dari kemiskinan yang selama ini dirasakannya, apapun akan mereka usahakan untuk bisa meyekolahkan anak-anak dan menghidupi keluarga. Mereka memiliki semangat kerja yang tinggi, tidak terpengaruh oleh cuaca, mereka pergi ke sampah di pagi hari agar mendapatkan hasil pulungan yang lebih banyak, yang berarti mendapatkan uang yang lebih. Telah nampak perubahan dalam kehidupan pemulung di TPA Air Dingin kearah hidup yang lebih baik, walaupun memerlukan waktu yang sangat lama.
\end{abstract}

Keywords: scavenger community, life quality, education.

(C2015 Prodi Pendidikan Ekonomi STKIP PGRI, Padang 


\section{PENDAHULUAN}

Pendidikan merupakan salah satu dari berbagai investasi manusia yang sangat memberikan andil dalam meningkatkan kualitas Sumber Daya Manusia (SDM). Dengan pendidikan seorang individu dapat meningkatkan pengetahuan dan ketrampilannya sehingga menjadi manusia yang berkualitas sesuai dengan harapan. Kualitas sumber daya manusia yang baik diharapkan dapat membuka cakrawala berfikir, memperluas wawasan, serta menguasai pemanfaatan ilmu pengetahuan dan teknologi yang akhirnya dapat memberikan kontribusi yang besar, baik dalam kehidupannya maupun dalam memajukan pembangunan nasional.

Pendidikan merupakan usaha agar manusia dapat mengembangkan potensi dirinya melalui proses pembelajaran atau cara lain yang dikenal dan diakui oleh masyarakat. Undang-Undang Dasar Negara Republik Indonesia Tahun 1945 Pasal 31 ayat (1) menyebutkan bahwa "Setiap warga negara berhak mendapatkan pendidikan", dan ayat (3) menegaskan bahwa "Pemerintah mengusahakan dan menyelenggarakan satu sistem pendidikan nasional yang meningkatkan keimanan dan ketaqwaan serta akhlak mulia dalam rangka mencerdaskan kehidupan bangsa yang diatur dalam Undang-Undang”. Untuk itu seluruh komponen bangsa wajib mencerdaskan kehidupan bangsa yang merupakan salah satu tujuan negara Indonesia.

Yahya (2009: 1) bahwa pendidikan memiliki dampak yang positif terhadap perkembangan suatu bangsa dalam berbagai aspek. Penanaman modal pada sumber daya manusia melalui proses pendidikan adalah sesuatu yang sangat menguntungkan bagi percepatan dan pertumbuhan ekonomi. Dengan demikian, investasi yang dilakukan dalam diri manusia dinamakan dengan human capital. Unsur modal manusia adalah pengetahuan, pengalaman, keterampilan dan kemampuan inovasi.

Irianto (2011: 17) menjelaskan bahwa proses perolehan pengetahuan dan keterampilan melalui pendidikan bukan merupakan suatu bentuk konsumsi semata-mata, akan tetapi juga merupakan suatu investasi. Hal ini mempunyai makna bahwa pengalokasian dana dibidang pendidikan merupakan kegiatan investasi dalam pembangunan secara menyeluruh melalui peningkatan kompetensi sumber daya manusia.

Pendapat di atas menjelaskan bahwa pendidikan merupakan salah satu investasi yang harus dimiliki oleh manusia, proses perolehan pengetahuan dan keterampilan melalui pendidikan bukan sekedar sebagai suatu kegiatan konsumtif, melainkan suatu bentuk investasi sumber daya manusia. Pendidikan yang tinggi yang dimiliki seseorang secara tidak langsung akan mempengaruhi percepatan dan pertumbuhan ekonomi.

Hasbullah (2005: 1) pendidikan adalah usaha manusia untuk membina kepribadiannya sesuai dengan nilai-nilai di dalam masyarakat dan kebudayaan. Selanjutnya Mudyaharjo (2002: 3) mengartikan pendidikan sebagai segala situasi hidup yang mempengaruhi pertumbuhan individu. Dari pengertian ini dapat dipahami bahwa pendidikan dilakukan untuk membina sebuah kepribadian yang sesuai dengan nilai-nilai dalam masyarakat dan kebudayaan, dimulai sejak manusia berada di muka bumi, atau bahkan sejak dalam kandungan. Dengan pendidikan yang tinggi diasumsikan seseorang akan dapat dengan mudah mendapatkan pekerjaan yang layak, yang akan berpengaruh pada penghasilan/pendapatannya. 
Kehidupannya akan semakin baik, karena bisa memenuhi segala kebutuhan yang diinginkannya.

Kota Padang merupakan kota yang berada di Sumatera Barat, memiliki 11 kecamatan yaitu Bungus Teluk Bangus, Lubuk Kilangan, Lubuk Begalung, Padang Selatan, Padang Timur, Padang Barat, Padang Utara, Nanggalo, Kuranji, Pauh dan Koto Tangah. Lokasi TPA Air Dingin terletak di Kelurahan Balai Gadang, Kecamatan Koto Tangah Padang. Luas TPA Air Dingin $\pm 30 \mathrm{ha}$, lahan yang sudah terpakai adalah 18,3 ha, dan sisanya 11,7ha masih belum digunakan. Berjarak $\pm 1 \mathrm{~km}$ dari pemukiman penduduk Balai Gadang.
Aspek terpenting bagi masyarakat yang berada dalam kondisi ekonomi rendah atau miskin yaitu mencari nafkah dengan cara yang simpel dan tidak memerlukan keterampilan yang dapat membuatnya terbebani. Hal ini dialami oleh sebagian warga masyarakat Indonesia khususnya pemulung. Dengan tingkat pendidikan yang hampir rata-rata rendah, tidak memiliki keahlian khusus, dan minimnya pengalaman kerja, membuat mereka tersingkir dari persaingan memperebutkan pekerjaan disektor formal. Terdapat sekitar 133 orang pemulung di TPA Air Dingin Kota Padang.

Tabel 1. Data Pemulung TPA Air Dingin Kota Padang Tahun 2013

\begin{tabular}{lcl}
\hline Jenis Kelamin & $\begin{array}{c}\text { Jumlah } \\
\text { Pemulung }\end{array}$ & Keterangan \\
\hline Laki-laki & 71 & Dewasa \\
Perempuan & 54 & Dewasa \\
Anak laki-laki & 6 & Anak-anak \\
Anak perempuan & 2 & Anak-anak \\
\hline Jumlah & 133 & \\
Sumber: TPA Air Dingin & &
\end{tabular}

Dari tabel di atas terdapat pemulung dewasa 125 orang (laki-laki 71 orang dan perempuan 54 orang), dan pemulung anak-anak 8 orang. Dimungkinkan data pemulung yang sebenarnya bisa melebihi dari jumlah di atas, karena ada pemulung musiman yang tidak terdeteksi, maksudnya mereka ikut memulung hanya sebagai kerja sampingan saja sebelum mereka mendapatkan pekerjaan yang layak. Tingkat pendidikan para pemulung juga sangat rendah, menyebabkan mereka tidak dapat bersaing untuk mendapatkan pekerjaan disektor formal. Data pendidikan pemulung di TPA Air Dingin baik yang sudah menamatkan sekolah (dewasa) maupun yang masih sekolah (anak-anak) adalah sebagai 
Tabel 2. Tingkat Pendidikan Pemulung

\begin{tabular}{cccccc}
\hline \multirow{2}{*}{ No. } & \multirow{2}{*}{ Pendidikan akhir } & \multicolumn{2}{c}{ Dewasa } & \multicolumn{2}{c}{ Anak-anak } \\
& Laki-laki & Perempuan & Laki-laki & Perempuan \\
\hline 1 & Tidak Tamat SD & 8 & 7 & - & - \\
2 & SD & 25 & 28 & 4 (sekolah) & 1 (sekolah) \\
3 & SMP & 33 & 12 & 2 (sekolah) & \\
4 & SMA & 5 & 6 & - & 1 (sekolah) \\
5 & Mahasiswa & - & 1 (kuliah) & - & - \\
\hline & Jumlah & 71 & 54 & 6 & 2 \\
\hline
\end{tabular}

Sumber: TPA Air Dingin

Data di atas menunjukan bahwa pemulung dewasa yang tidak tamat SD 15 orang $(11,28 \%)$, tamat SD sebanyak 53 orang $(39,85 \%)$, tamat SMP 45 orang $(33,83 \%)$, tamat SMA 11 orang $(8,27 \%)$ dan terdapat 1 orang mahasiswa $(0,75 \%)$ yang saat ini masih belajar disalah satu Perguruan Tinggi di Kota Padang. Untuk pemulung anak-anak dan masih sekolah berjumlah 8 orang, SD 5 orang $(3,76 \%)$, SMP 2 orang $(1,50 \%)$ dan SMA 1 orang $(0,75 \%)$.

Penghasilan komunitas pemulung ini setiap harinya berkisar antara $\mathrm{Rp}$. 40.000,00 - Rp. 70.000,00 (Sumarni, 2011). Uang yang diperoleh biasanya untuk memenuhi kebutuhan hidup seharihari. Ini artinya mereka bisa mengumpulkan antara Rp. 1.200.000,00 Rp. 2.100.000,00/bulan. Jumlah ini berada di atas jumlah Upah Minimum Propinsi (UMP) yang ditetapkan oleh pemerintah Propinsi Sumatera Barat yaitu sebesar Rp. 1.150.000,00. Dengan jumlah penghasilan tersebut seharusnya mereka dapat hidup lebih baik, tetapi kondisi kehidupan mereka masih terkesan serba kekurangan, dan terbelakang. Penelitian ini mengungkapkan tentang Kualitas Hidup Komunitas Pemulung di Tempat Pembuangan Akhir (TPA) Air Dingin Kota Padang di Tinjau dari Segi Pendidikan

\section{METODOLOGI}

Pendekatan yang digunakan dalam penelitian ini adalah pendekatan kualitatif yaitu penelitian yang menghasilkan data deskriptif berupa kata-kata tertulis atau lisan dari orang-orang dan perilaku yang dapat diamati. Pendekatan analisis yang digunakan adalah pendekatan analisis deskriptif, yaitu penelitian yang tujuannya untuk menguraikan, menerangkan atau menjelaskan secara mendalam tentang variabel tertentu yang ada dalam suatu masyarakat.

Lokasi penelitian ini di Kelurahan Balai Gadang Kecamatan Koto Tangah Padang Sumatera Barat tepatnya di Tempat Pembuangan Akhir (TPA) Air Dingin. Berjarak $\pm 2 \mathrm{~km}$ dari jalan raya bypass Lubuk Minturun, $\pm 17 \mathrm{~km}$ dari Pusat Kota Padang dan $\pm 7 \mathrm{~km}$ dari tempat pemukiman penduduk, mempunyai luas sekitar $30 \mathrm{Ha}$. Dengan jumlah informan 32 (tiga puluh dua) orang, terdiri dari pemulung 22 (dua puluh dua) orang, pegawai TPA Air Dingin 3 (tiga) orang, masyarakat sekitar 3 (tiga) orang, pelajar (anak pemulung) 2 (dua) orang, pegawai BPS 1 (satu) orang dan pegawai Kelurahan Balai Gadang 1 (satu) orang.

Pemilihan informan dilakukan dengan sengaja (purposive sampling), di mana informan penelitian dipilih sesuai dengan maksud dan tujuan penelitian. 
Informan adalah subjek penelitian yang ditentukan sebagai sumber informasi yang relevan dengan permasalahan penelitian, oleh karena itu informan dalam penelitian ini adalah orang yang terlibat langsung sebagai pemulung di TPA Air Dingin Kelurahan Balai Gadang Kecamatan Koto Tangah Padang, dan orang-orang yang memahami situasi dan kondisi di sekitar TPA Air Dingin.

Penelitian ini terdiri dari dua jenis data yaitu data primer dan data sekunder. Data primer data yang diperoleh langsung dari responden dalam hal ini adalah komunitas pemulung di Tempat Pembuangan Akhir (TPA) Air Dingin. Data sekundernya adalah data yang berkaitan dengan keadaan geografis dan demografi.

Teknik yang dipakai untuk mendapatkan data dengan:

\section{Observasi}

Peneliti mengamati para pemulung saat memungut sampah, hingga mereka beristirahat sekitar pukul $12.00 \mathrm{Wib}$ untuk makan, sholat dzuhur, dan membersihkan hasil pulungan kemudian memisahkannya berdasarkan jenisnya, hingga akhirnya hasil pulungan tersebut dijemput oleh mobil agen/pengepul sekitar pukul 16.00 Wib untuk dibawa ke penimbangan. Kemudian para pemulung ini tinggal berjalan kaki menuju tempat penimbangan. Peneliti juga mengikuti proses penimbangan hingga selesai sampai akhirnya para pemulung menerima hasil jerih payahnya sekitar pukul $17.00 \mathrm{Wib}$, baru mereka pulang ke rumah masing-masing.

Atas informasi yang disampaikan oleh Bapak Syahrial, S.Sos. selaku Pengawas Umum dan Kebersihan di TPA Air Dingin, peneliti mendatangi rumah mereka yang berada di belakang
SMP N 16 Padang, peneliti mengamati lingkungan tempat tinggal mereka sebelum peneliti melanjutkan untuk ke proses wawancara. Sebelumnya mereka curiga, bahkan terkesan cuek, setelah peneliti memperkenalkan diri secara baik-baik kebeberapa pemulung yang berada di sekitar rumah mereka bahwa peneliti akan mengambil data penelitian dan mengungkapkan tujuan penelitian yang sebenarnya, maka peneliti diberi peluang untuk mewawancarai mereka keesokan harinya.

Dalam proses observasi peneliti terlibat sebagai instrument utama, peneliti mendatangi tempat informan secara langsung untuk melihat, mendengar, dan mengamati aktivitasaktivitas yang dilakukan oleh para pemulung di TPA Air Dingin yang berkaitan dengan tujuan penelitian. Kegiatan observasi ini dilakukan berulang-ulang sampai diperoleh data yang dibutuhkan. Penelitian ini dilakukan \pm 2 (dua) bulan dimulai dari awal bulan November 2013 sampai akhir Desember 2013.

\section{Wawancara}

Wawancara dalam penelitian ini berjumlah 32 (tiga puluh dua) orang. Khusus untuk para pemulung karena saat bekerja di sampah mereka tidak bersedia diwawancarai, maka peneliti memutuskan untuk langsung mendatangi rumah mereka disore hari sekitar pukul 17.30 Wib, saat mereka sudah pulang dari memulung dan sudah membersihkan diri, wawancara berlangsung hingga malam hari sekitar pukul 21.00. Wawancara berlangsung di rumah masing-masing pemulung, peneliti mendatangi rumah mereka satu persatu, dengan suasana yang sangat akrab mereka memberikan jawaban 
dari semua pertanyaan yang peneliti tanyakan. Untuk pegawai di TPA Air Dingin, pegawai BPS dan pegawai kelurahan peneliti mewawancarainya saat jam kerja berlangsung. Sementara untuk masyarakat setempat seperti ketua RT, agen/pengepul peneliti tidak terikat oleh waktu dalam arti kapan saja bisa dilakukan.

\section{Dokumentasi.}

Menurut Mestika Zed (2004: 4) idealnya sebuah riset professional menggunakan kombinasi riset pustaka dan lapangan. Riset pustaka yang digunakan dalam penelitian ini diperoleh dari perpustakaan Universitas Negeri Padang, Dinas Kebersihan dan Pertamanan (DKP) Kota Padang, Badan Pusat Statistik (BPS) Kota Padang, Kantor Camat Koto Tangah dan Kantor Lurah Balai Gadang dengan tujuan menambah keakuratan data yang bersifat administratif. Di samping itu peneliti juga mengumpulkan dokumen pribadi berupa foto-foto selama proses penelitian berlangsung.

Untuk memperkuat kesahihan data penelitian, maka peneliti mengacu kepada penggunaan standard dari Lincoln dan Guba (1985 : 189) yaitu credibility, transferability, dependability, confirmability.

\section{Kriteria Kredibilitas}

Agar hasil penelitian kualitatif memiliki tingkat kepercayaan yang tinggi sesuai dengan fakta di lapangan, perlu dilakukan upaya-upaya sebagai berikut:

a. Memperpanjang keikutsertaan peneliti dalam proses pengumpulan data di lapangan. Tidak terhitung lagi kehadiran peneliti di tengah-tengah kehidupan para pemulung, peneliti pun sangat akrab dengan mereka. Sehingga apa yang peneliti inginkan yang sesuai dengan tujuan penelitian dengan mudah peneliti dapatkan.

$b$. Melakukan observasi secara terus menerus dan sungguh-sungguh, sehingga peneliti semakin mendalami fenomena sosial yang diteliti seperti apa adanya. Peneliti berperan sebagai partisipan pasif dalam arti peneliti tidak ikut memulung, karena memang tidak diperbolehkan oleh petugas setempat untuk langsung turun ke sampah, dengan alasan sangat berbahaya karena musim hujan, sehingga jalanan sangat licin.

c. Melakukan triangulasi, yaitu peneliti membandingkan dari satu pertanyaan terhadap jawaban yang sama dari beberapa pemulung, baru kemudian dilakukan analisis. Dengan triangulasi ini peneliti memperoleh variasi informasi seluas-luasnya atau selengkaplengkapnya, teknik pemeriksaan dengan menggunakan triangulasi sumber yaitu membandingkan dan mengecek balik kepercayaan derajat suatu informasi yang diperoleh melalui waktu dan alat yang berbeda.

d. Melibatkan teman sejawat (yang tidak ikut melakukan penelitian) untuk berdiskusi, memberikan masukan, bahkan kritik mulai awal kegiatan proses penelitian sampai tersusunnya hasil penelitian (peer debriefing).

e. Melakukan analisis atau kajian kasus negative, yang dapat dimanfaatkan sebagai pembanding atau bahkan sanggahan terhadap hasil penelitian. Pemulung selalu 
diidentikan dengan hal-hal yang negative, seperti kumuh, jorok, suka mencuri akan tetapi hal ini tidak mutlak dilakukan oleh mereka. Komunitas pemulung yang berada di TPA Air Dingin tidak mencari barang pulungan ke luar area TPA, akan tetapi mereka mencari barang pulungan di dalam TPA Air Dingin dan mereka tinggal mengambil saja.

$f$. Mengecek bersama-sama dengan anggota penelitian yang terlibat dalam proses pengumpulan data, baik tentang data yang telah dikumpulkan, kategorisasi analisis, penafsiran dan kesimpulan hasil penelitian. Dalam hal ini peneliti tidak memiliki anggota penelitian untuk itu peneliti mengadakan pengecekan terhadap data yang dikumpulkan, hingga pada proses analisis data dilakukan secara individu.

\section{Kriteria Transferabilitas}

Pada prinsipnya, standar transferabilitas merupakan pertanyaan empirik yang tidak dapat dijawab oleh peneliti kualitatif itu sendiri, tetapi dijawab dan dinilai oleh para pembaca laporan penelitian. Hasil penelitian kualitatif memiliki standar transferabilitas yang tinggi bilamana para pembaca laporan sebuah penelitian memperoleh gambaran dan pemahaman yang jelas tentang konteks dan fokus penelitian.

\section{Kriteria Dependabilitas}

Makin konsisten peneliti dalam keseluruhan proses penelitian, baik dalam kegiatan pengumpulan data, interprestasi temuan maupun dalam melaporkan hasil penelitian, akan semakin memenuhi standard dependabilitas. Peneliti berusaha konsistensi dalam keseluruhan proses penelitian agar dapat memenuhi syarat yang berlaku. Semua aktivitas penelitian telah ditinjau ulang terhadap data yang diperoleh dengan memperhatikan konsistensi dan dapat dipertanggungjawabkan. Konsistensi dalam penelitian ini dipertahankan agar dapat memenuhi syarat yang berlaku.

\section{Kriteria Konfirmabilitas}

Standar konfirmabilitas lebih terfokus pada audit (pemeriksaan) kualitas dan kepastian hasil penelitian, apa benar berasal dari pengumpulan data dilapangan. Untuk keperluan kepastian, peneliti memperhatikan hasil catatan yang peneliti buat selama proses penelitian berlangsung dan juga rekaman wawancara di lapangan, sehingga penelitian ini dapat dipertanggungjawabkan dan diakui sesuai dengan fokus dan latar belakang penelitian yang dilakukan.

Analisis data merupakan upaya mencari dan menata secara sistematis catatan hasil observasi, wawancara, dan lainnya kemudian menyajikannya sebagai temuan bagi orang lain. Moleong (2001: 103) mengemukakan analisa data merupakan proses mengatur urutan data, mengorganisasikannya ke dalam satu pola, kategori dalam satuan uraian dasar. Proses analisa data dimulai dengan menelaah data dan melakukan reduksi data yang dilakukan dengan membuat abstrasi, menyusun dalam satuan-satuan, kategorisasi, sambil membuat coding (pengkodean), mengadakan pemeriksaan keabsahan data. Setelah proses tersebut selesai barulah dilakukan penafsiran data.

Teknik analisa data menggunakan analisis data kualitatif, aktifitas analisis 
data penelitian meliputi reduksi data, penyajian data, dan penarikan kesimpulan. Hal ini sesuai yang dikemukakan oleh Miles dan Huberman (1992: 15-20) yaitu aktifitas dalam analisis data kualitatif dilakukan secara interaktif dan berlangsung secara terus menerus pada setiap tahapan penelitian sehinggaa sampai tuntas dan datanya sampai jenuh. Aktifitas analisis data antara lain:

\section{Reduksi Data (data reduction)}

Merupakan proses pemilihan, pemusatan perhatian pada penyederhanaan, pengabstsrakan dan transformasi data kasar yang muncul dari catatan tertulis di lapangan yang berlangsung terus menerus selama proses penelitian. Reduksi data adalah bentuk analisis yang menajamkan, menggolongkan, membuang yang tidak perlu dan mengorganisasikan data sehingga kesimpulan-kesimpulan akhir dapat ditarik dan diverifikasi.

Peneliti mengadakan pencatatan terhadap hasil pengamatan dan hasil wawancara terhadap komunitas pemulung di TPA Air Dingin, baik itu yang berhubungan dengan pekerjaannya ataupun kehidupannya atau hal lainnya, setelah itu peneliti mengadakan pengecekan kembali dengan membuang data yang dianggap tidak perlu atau tidak sesuai dengan tujuan penelitian, mengelompokan data berdasarkan permasalahannya dengan memberikan kode-kode terhadap data tersebut.

\section{Penyajian Data (data display)}

Merupakan kegiatan menampilkan sekumpulan informasi tersusun yang memberikan kemungkinan adanya penarikan kesimpulan dan pengambilan tindakan selanjutnya. Penyajian data yang baik akan memudahkan peneliti dalam menganilis data dan dapat menyajikan data kualitatatif yang valid. Setelah reduksi data selesai maka peneliti mengadakan penyusunan data berdasarkan kode-kode yang sudah dibuat. Data dikelompokan sesuai dengan hasil temuan selama proses penelitian. Dalam hal ini peneliti menyajikannya dalam bentuk pertanyaan penelitian, identitas subjek dan uraian singkat dari jawaban yang diberikan.

\section{Menarik Kesimpulan/verifikasi (conclution drawing/verification)}

Setelah melalui tahap reduksi data dan display data, maka langkah selanjutnya peneliti menganalisis data dengan menarik kesimpulan dari datadata yang telah tersusun secara sistematis tersebut, kemudian melakukan verifikasi, yaitu menguji kebenaran dan kekokohannya yang menunjukan validitas (keabsahannya). Apabila terjadi kesalahan data yang mengakibatkan kesimpulan tidak sesuai maka dapat dilakukan proses ulang dengan melalui tahapan yang sama.

\section{HASIL PENELITIAN DAN PEMBAHASAN}

Pendidikan merupakan investasi yang sangat berharga, dengan pendidikan seseorang akan dapat meningkatkan pengetahuan dan ketrampilannya sehingga menjadi manusia yang berkualitas. Diasumsikan semakin tinggi tingkat pendidikan seseorang maka akan semakin tinggi pula tingkat penghasilannya. Tinggi rendahnya penghasilan tersebut sangat berpengaruh terhadap kualitas hidupnya, baik dari segi pemenuhan terhadap sandang, pangan, papan, kesehatan, dan juga kebutuhan akan pendidikan setiap anggota keluarga. Pendidikan adalah suatu proses dalam upaya mencerdaskan kehidupan bangsa, oleh sebab itu mustahil 
kemajuan akan dicapai tanpa memperhatikan bidang pendidikan baik mutu maupun sarana dan prasarananya. Dilihat dari penduduk usia sekolah yaitu umur 5 sampai 24 tahun Kecamatan Koto Tangah pada tahun 2012, penduduk usia sekolahnya berjumlah 68.238 orang atau sekitar 40,57 persen dari jumlah penduduk Kecamatan Koto Tangah. Untuk Kelurahan Balai Gadang jumlah sekolah, banyaknya kelas, banyaknya tenaga pengajar, jumlah murid serta lulusan pada tahun 2012 dapat dilihat pada tabel di bawah ini:

Tabel 3. Sarana Pendidikan Kelurahan Balai Gadang

\begin{tabular}{lccccc}
\hline $\begin{array}{c}\text { Nama } \\
\text { sekolah }\end{array}$ & $\begin{array}{c}\text { Jumlah } \\
\text { sekolah }\end{array}$ & $\begin{array}{c}\text { Jumlah } \\
\text { kelas }\end{array}$ & $\begin{array}{c}\text { Jumlah } \\
\text { guru }\end{array}$ & $\begin{array}{c}\text { Jumlah } \\
\text { murid }\end{array}$ & $\begin{array}{c}\text { Jumlah } \\
\text { lulusan }\end{array}$ \\
\hline SD Negeri & 9 & 57 & 95 & 1.572 & 213 \\
SMP Negeri & 1 & 17 & 71 & 825 & 209 \\
SMP Swasta & 1 & 14 & 37 & 409 & 106 \\
SMA Negeri & 1 & 15 & 64 & 490 & 145 \\
SMA Swasta & 1 & 8 & 44 & 213 & 66 \\
MAN & 1 & 6 & 44 & 213 & 66 \\
\hline
\end{tabular}

Sumber: Dinas Pendidikan Kota Padang

Seperti terlihat dalam tabel di atas bahwa Kelurahan Balai Gadang memiliki 9 buah Sekolah Dasar Negeri, 1 buah SMP Negeri yaitu SMP Negeri 16 Padang, 1 buah SMP Swasta yaitu SMP Swasta di Perguruan Ar-risalah, 1 buah SMA Negeri yaitu SMA N 13 Padang dan MAN 3 Padang, 1 buah SMA Swasta yaitu SMA Swasta di Perguruan Arrisalah. Sementara tidak terdapat Perguruan Tinggi baik negeri maupun swasta di Kelurahan Balai Gadang Kecamatan Koto Tangah ini. Bagi siswa Sekolah Dasar rata-rata mereka pergi ke sekolah dengan berjalan kaki karena memang dekat dengan tempat tinggal. Sementara untuk siswa SMP dan SMA ada sebagian dari mereka yang di antar oleh orang tuanya dan ada yang berjalan kaki. Bagi yang rumahnya jauh pulangnya dengan angkot yang sangat mudah didapat karena lokasi sekolah ini ditepi jalan besar, hanya sebagian kecil yang pulangnya di jemput oleh orang tuanya.
Berbagai upaya telah dilakukan oleh pemerintah, salah satunya adalah program wajib belajar 9 tahun, yang dimulai sejak tahun 1994 hingga sekarang. Dengan semakin lamanya usia belajar diharapkan tingkat pendidikan penduduk semakin membaik, dan tentunya akan berpengaruh pada kualitas sumber daya manusia. Di Kelurahan Balai Gadang ini terdapat beberapa sekolah negeri juga swasta, baik tingkat SD, SMP, SMA. Masyarakat sekitar sini benar-benar memanfaatkan sarana pendidikan yang ada di sini, bahkan masyarkat di luar Kelurahan Balai Gadang juga ikut memanfaatnya, mereka menyekolahkan anaknya ke sini, biasanya untuk tingkat SMP dan SMA. Bagi komunitas pemulung yang tinggal di sekitar TPA Air Dingin pendidikan merupakan sesuatu yang sangat mahal harganya. Untuk menambah pendidikan khususnya pendidikan formal mungkin dapat dikatakan sudah terlambat, karena usia mereka rata-rata sudah lanjut. Akan tetapi masih ada harapan untuk anak-anak 
mereka. Seperti yang diungkapkan oleh bapak Azwardi, S.H. kepala UPT di lingkungan TPA Air Dingin, "Rata-rata pemulung di sini pendidikannya rendah, bahkan ada yang tidak tamat Sekolah Dasar, akan tetapi sebagian dari anakanak mereka ada yang tamat SLTA bahkan ada yang kuliah, ini berarti mereka memiliki semangat yang tinggi untuk menyekolahkan anaknya”. Kalau mereka ditanya mengapa mau jadi pemulung, jawabanya hampir sama, agar anak-anak bisa tetap sekolah.
Walaupun pendidikannya rendah mereka sangat menginginkan anaknya tetap bisa bersekolah hingga ke jenjang yang lebih tinggi, walaupun nyawanya harus dipertaruhkan di sampah. Hal ini sudah dibuktikan bahwa anak-anak mereka banyak yang sekolah, dan hanya sedikit yang putus sekolah, bahkan ada yang melanjutkan hingga ke perguruan tinggi. Dengan harapan agar kehidupan generasi keturunannya bisa lebih baik lagi, mereka tidak menginginkan keturunannya menjadi pemulung juga.

Tabel 4. Pendidikan Anak Keluarga Pemulung di TPA Air Dingin Kota Padang (17 Kepala Keluarga)

\begin{tabular}{lccl}
\hline \multicolumn{1}{c}{ Pendidikan } & $\begin{array}{c}\text { Jumlah } \\
\text { (orang) }\end{array}$ & Prosentase & Keterangan \\
\hline Paud/TK & 10 & 13,88 & Sekolah \\
Tidak Tamat SD & 4 & 5,56 & Putus sekolah \\
SD & 17 & 23,61 & Sekolah \\
Tamat SD & 7 & 9,72 & Putus sekolah \\
SMP & 4 & 5,56 & Sekolah \\
Tamat SMP & 7 & 9,72 & Putus sekolah \\
SMA & 4 & 5,56 & Sekolah \\
Tamat SMA & 17 & 23,61 & Bekerja \\
PT & 1 & 1,39 & Kuliah \\
Tamat PT & 1 & 1,39 & Bekerja \\
\hline \multicolumn{1}{c}{ Total } & 72 & 100 & - \\
\hline
\end{tabular}

Sumber: Data olahan peneliti 2014 
Dari data di atas dapat dilihat bahwa anak pemulung yang sedang sekolah berjumlah 36 orang anak (50\%), yang tamat SMA juga PT dan sudah bekerja 18 orang anak $(25 \%)$, sedangkan yang putus sekolah 18 orang anak $(25 \%)$. Hal ini menunjukan bahwa anak-anak pemulung lebih banyak yang berpendidikan dari pada yang putus sekolah, hal ini sesuai dengan cita-cita para pemulung bahwa mereka ingin sekali menyekolahkan anak-anak hingga ke jenjang yang lebih tinggi. Mereka memiliki semangat yang tinggi untuk bisa merubah hidup, mereka berusaha agar anaknya dapat terus bersekolah ke jenjang yang lebih tinggi. Agar kelak dapat dengan mudah mendapatkan pekerjaan. Hal ini sesuai dengan apa yang disampaikan oleh penganut fungsionalis, bahwa jangan sampai masyarakat kehilangan peluang untuk meraih tingkat pendidikan yang baik. Kalau hal itu terjadi, maka nasibnya akan tidak beruntung. Sulit mendapatkan pekerjaan yang baik, pekerjaan yang bisa mendatangkan keuntungan besar hanya akan diperoleh oleh masyarakat yang memiliki pendidikan yang memadai (Maliki, 2008:45).

Diasumsikan ketika seseorang memiliki pendidikan tinggi, kemungkinan besar ia memiliki peluang untuk mendapatkan pekerjaan, dengan begitu kehidupannya mulai terarah pada yang lebih baik lagi. Dengan pekerjaan yang dimilikinya berarti ia memiliki penghasilan yang akan membawanya pada kesejahteraan hidup baik untuk dirinya juga keluarganya. Para pemulung menyadari bahwa ia memiliki pendidikan yang rendah, untuk itu mereka berusaha agar anak-anaknya bisa bersekolah hingga kejenjang yang lebih tinggi. Todaro (2011: 464) menjelaskan terdapat korelasi yang positif antara tingkat pendidikan seseorang dengan penghasilannya seumur hidup. Korelasi tersebut dapat dilihat terutama pada mereka yang menyelesaikan sekolah menengah dan universitas. Pendapatan mereka 300 persen hingga 800 persen lebih besar dari pada pendapatan para pekarja yang hanya berpendidikan sekolah dasar atau kurang dari itu. Karena tingkat penghasilan sangat dipengaruhi oleh tingkat pendidikan, maka ketimpangan pendapatan akan bertambah buruk, mengingat para pelajar dari keluarga yang berpenghasilan tinggi jauh lebih besar peluangnya untuk meneruskan pendidikannya sampai ke jenjang tertinggi, sementara anak-anak dari keluarga kurang mampu sangat sulit untuk meneruskan pendidikannya. Dari penelitian ini dapat diketahui bahwa kualitas hidup komunitas pemulung di TPA Air Dingin sudah mulai ada peningkatan kearah yang lebih baik, terlihat dari semangat yang tinggi untuk meyekolahkan anaknya, pemikiran positif untuk merubah nasib pada arah yang lebih baik, tidak menginginkan anaknya menjadi pemulung

\section{PENUTUP}

Setiap manusia selalu menginginkan perubahan dalam hidupnya pada arah yang lebih baik, segala cara dilakukan dan diusahakan untuk mewujudkannya, walaupun terkadang menemui kegagalan. Untuk mewujudkan sebuah kesuksesan maka manusia harus mempunyai bekal yang cukup, seperti pendidikan, pengalaman, keterampilan dan lain sebagainya. Apa yang menjadi harapan komunitas pemulung merupakan hal yang wajar, karena pekerjaan memulung sangat berat untuk dijalani, dan hanya mengandalkan tenaga fisik, yang tidak semua orang mau dan mampu menjalaninya. Untuk itu mereka bekerja keras agar dapat membiayai sekolah anaknya. Apapun akan mereka usahakan, karena dengan memberikan pendidikan yang tinggi pada anak, mereka beranggapan pada akhirnya nanti akan merasakan hasilnya. Dapat diketahui bahwa mereka memiliki semangat yang tinggi untuk menyekolahkan anak-anaknya, terbukti bahwa $75 \%$ anak-anak pemulung rata-rata bersekolah, dan $25 \%$ putus sekolah. Anakanak pemulung ini juga memiliki semangat yang tinggi untuk melanjutkan sekolah, dengan harapan agar hidupnya bisa berubah kearah yang lebih baik.

Sangat diperlukan keterlibatan Pemerintah Kota Padang untuk memperhatikan nasib kehidupan mereka selanjutnya, karena tidak mungkin selamanya mereka akan menjadi pemulung. Dengan 
memberikan bekal berupa pelatihan-pelatihan, kursus-kursus, penyululuhan-penyuluhan yang pada akhirnya bisa dimanfaatkan oleh para pemulung, sehingga mereka tidak menggantungkan dari hasil memulung saja. Pelatihan ini bisa dilakukan melalui organisasi-organisasi setempat, seperti melalui arisan RT atau majelis ta'lim. Untuk menambah pengetahuan bisa juga dibuat Taman Baca di sekitar TPA Air Dingin yang dibuat oleh pemeritah setempat.

\section{DAFTAR PUSTAKA}

10.22202/economica.2015.v4.i1.626

Anonim. 2009. Undang-undang Dasar Republik Indonesia 1945.Jakarta: Sandro Jaya.

Hasbullah. 2005. Dasar-dasar Ilmu Pendidikan. Jakarta: Raja Grafindo Persada.

Irianto, Agus. 2011. Pendidikan Sebagai Investasi Dalam Pembangunan Suatu Bangsa. Jakarta: Kencana Prenada Media Group.

Lincoln, Y.S and Guba, E.G. 1985. Naturalistic Inqury. California: SAGE Publications, Inc.

Maliki, Zainudin. 2008. Sosiologi Pendidikan. Yoyakarta: Gajah Mada University Press.

Miles dan Huberman. 1992. Analisis Data Kualitatif. Jakarta: Universitas Indonesia.

Moleong L. J. 2001. Metodologi Penelitian Kualitatif. Bandung: Remaja Rosdakarya.

Mudyahardjo, Redja. 2002. Pengantar Pendidikan: Sebuah Studi Awal Tentang Dasar-Dasar Pendidikan pada Umumnya dan Pendidikan di Indonesia. Jakarta: Raja Grafindo Persada.

Todaro, P Michael. 2011. Pembangunan Ekonomi, Jilid 1, Ed.9. Jakarta: Erlangga.

Yahya. 2009. Ekonomi dan Pembiayaan Pendidikan: Sebuah Pendekatan Akumulatif. Padang: Sukabina.

Zed, Mestika. 2004. Metode Penelitian Kepustakaan. Jakarta: Yayasan Obor Indonesia 